\title{
Improving barley yield on an acidic Boralf with crop rotation, lime, and zero tillage
}

\author{
M.A. Arshad ${ }^{\mathrm{a}, *}$, A.J. Franzluebbers ${ }^{\mathrm{b}}$, K.S. Gill ${ }^{\mathrm{a}}$ \\ ${ }^{a}$ Agriculture and Agri-Food Canada, Northern Agriculture Research Centre, Box 29, Beaverlodge, Alta., Canada TOH OCO \\ ${ }^{\mathrm{b}}$ A.J. Franzluebbers, USDA-Agricultural Research Service, 1420 Experiment Station Road, Watkinsville, GA 30677, USA
}

Received 8 December 1997; accepted 2 November 1998

\begin{abstract}
Alternatives to the traditional small grain-bare fallow system on the Canadian Prairies are needed to avoid long-term deterioration of soil quality and to stabilize income. Canola (Brassica campestris L.) or pea (Pisum sativum L.) replaced traditional bare fallow in a 3-year rotation with barley (Hordeum vulgare L.) on a Mollic Cryoboralf near Beaverlodge, Alberta. Liming (none and 7.5 $\mathrm{Mg} \mathrm{ha}^{-1}$ in 1991) and tillage [conventional shallow (CT) and zero tillage (ZT)] were factorially arranged with crop rotation to assess barley grain and stover production during 1993-1995. Barley grain yield was $11 \pm 5 \%$ greater during the first phase following canola or pea than during the second phase. During both phases in the rotation, barley yield was $8 \pm 5 \%$ greater with pea than with canola. Crop rotation had little effect on barley stover production. Liming increased barley grain yield $17 \pm 8 \%$ and stover yield $13 \pm 13 \%$, which could be attributed to the maintenance of soil $\mathrm{pH}$ at $6.2 \pm 0.1$ after liming compared with $5.0 \pm 0.1$ without liming. Zero tillage produced a grain yield advantage and a stover yield disadvantage in one of three years, but had no detrimental effect on stover or grain yield in other years. Volumetric soil water content of the surface $0-0.2 \mathrm{~m}$ under ZT was $0.03 \pm 0.02 \mathrm{~m}^{3} \mathrm{~m}^{-3}$ greater than under CT. Highest grain production (barleybarley-pea, limed, ZT) was $4.35 \pm 0.34 \mathrm{Mg} \mathrm{ha}^{-1}$, while lowest grain production (barley-barley-canola, unlimed, CT) was $2.88 \pm 0.53 \mathrm{Mg} \mathrm{ha}^{-1}$. Our results indicate that increased barley productivity could be achieved with pea compared with canola in rotation. Liming and ZT further improved barley yield on this acidic soil in the cold semiarid region of the Canadian Prairies. (C) 1999 Elsevier Science B.V. All rights reserved.
\end{abstract}

Keywords: Barley; Canola; Crop rotation; Lime; Pea; Tillage

\section{Introduction}

Sustainable agricultural development in the Canadian Prairies needs to address issues of:

1. farm income stability due to rising input costs and uncertain grain prices,

*Corresponding author. Tel.: +403-354-5110; fax: +403-354-8171; e-mail: arshadc@em.agr.ca
2. water quality deterioration as a result of soil erosion and losses of fertilizers, and

3. soil quality deterioration as a result of excessive tillage.

Small grain-fallow rotations have been traditionally employed to recharge soil moisture and allow time for inorganic nutrients to accumulate. Tillage during the fallow year, however, decreases long-term soil quality 
by accelerating soil organic matter loss, deteriorating soil structure, and removing the moisture-conserving residue layer on the soil surface (Hatfield and Stewart, 1994). Replacement of bare fallow with oilseeds and grain legumes may be one approach to increase crop diversification in order to lower risk of crop failure and capitalize on rotation benefits, which can improve and stabilize grain production and reduce input costs, while at the same time avoid the negative consequences of tilled fallow on water, soil, and air quality.

Improving grain production with crop rotations is dependent upon the selection of crop species and subsequent alterations in pest populations, residual soil moisture, and fertility (Campbell et al., 1990). Wheat (Triticum aestivum L.) grain yield increased during the first year following pea or lentil (Lens culinaris Medic.), but barley grain yield during the second year was unaffected by the legume crop (Brandt, 1996). Barley grain yield increased $21 \%$ during the first year and $12 \%$ during the second year following lentil, pea, or faba bean (Vicia faba L.) compared with following barley (Wright, 1990). Increased cereal grain yield following legumes has generally been attributed to improved $\mathrm{N}$ fertility through biological $\mathrm{N}$ fixation (Bezdicek et al., 1978; Mahler and Auld, 1989; Wani et al., 1994). However, benefits of legumes in crop rotation may also be due to non- $\mathrm{N}$ improvements in soil physical conditions (Karlen et al., 1994; Stevenson and van Kessel, 1996), elimination of phytotoxic substances and plant pathogenic microorganisms that build up with continuous cropping (Cook, 1984; Crookston et al., 1988), and an increase in the ratio of beneficial-todetrimental soil organisms (Fyson and Oaks, 1990; Jawson et al., 1993).

Non-legume crop rotation effects on small grain production have been observed in some, but not all studies. Wheat grain yield was $12 \%$ greater following canola than following wheat, and barley grain yield was $9 \%$ greater following canola than following wheat (Brandt and Zentner, 1995). Compared with wheat yield during the first year following flax (Linum usitatissimum L.), oat (Avena sativa L.) hay, corn (Zea mays L.) silage, or potato (Solanum tuberosum L.), wheat grain yield during the second year was $87 \%$ on a sandy loam and $74 \%$ on a clay loam (Spratt et al., 1975). Averaged across 18 years, wheat grain yield was similar when grown continuously as in 3-year rotations with oat or flax (Zentner and Campbell, 1988).

Conservation tillage is known to improve soil moisture retention especially early in the growing season (Arshad et al., 1995; Franzluebbers and Arshad, 1996) and this may be important in expressing crop root responses to the presence of beneficial or detrimental soil organisms. However, the interactions that might occur between conservation tillage and crop rotation on small grain yields in the Canadian Prairies have not been investigated.

Liming of acidic soils can improve yield substantially (Hoyt and Hennig, 1982; Malhi et al., 1995), yet widespread use of lime in the Peace River region has not been adopted. Crop response to liming may be altered under conservation tillage due to potential changes in soil moisture, soil organic matter, and root distribution. However, this information is lacking in the Canadian Prairies.

Producers in western Canada recognize the importance of adequate soil fertility, crop diversity, and soil cover in maintaining a sustainable food production system, but lack details on the effect of various combinations of these best management practices. Our objective was to quantify barley grain and stover production in response to:

- inclusion of canola or pea in a 3-year rotation with barley,

- liming, and

- tillage management.

\section{Materials and methods}

A field experiment was established in 1991 on a Hythe clay loam [Gray Luvisol (Canada Soil Survey Committee, 1978); fine, montmorillonitic, frigid Mollic Cryoboralf (Soil Survey Staff, 1994)] near Beaverlodge, Alberta $\left(55^{\circ} 11^{\prime} \mathrm{N}, 119^{\circ} 32^{\prime} \mathrm{W}\right)$ that was previously cropped under conventional management (barley-fallow with mouldboard plough to a depth of $150 \mathrm{~mm}$ until late sixties when less intensive residue incorporation by chiseling became typical). Annual temperature and precipitation average $2{ }^{\circ} \mathrm{C}$ and $452 \mathrm{~mm}$, respectively. Growing season (April-September) precipitation averages $261 \mathrm{~mm}$, class A pan evaporation averages $831 \mathrm{~mm}$, temperature averages 
$12.5^{\circ} \mathrm{C}$, and growing degree days $\left(\geq 5^{\circ} \mathrm{C}\right)$ average $1224^{\circ} \mathrm{C}$ days. To a depth of $0.2 \mathrm{~m}$, soil contained $220 \mathrm{~g}_{\text {sand }} \mathrm{kg}^{-1}, 340 \mathrm{~g}$ clay kg $\mathrm{kg}^{-1}, 32 \mathrm{~g}$ soil organic $\mathrm{C} \mathrm{kg}^{-1}, 28 \mathrm{cmol}_{\mathrm{c}} \mathrm{kg}^{-1}, 81 \%$ base saturation, and had a pH (1:2, soil:0.01 $\left.\mathrm{M} \mathrm{CaCl}_{2}\right)$ of 5.1.

The experimental design was a split plot. Liming (none and $7.5 \mathrm{Mg} \mathrm{CaCO}_{3}$ equivalent $\mathrm{ha}^{-1}$ ) and tillage (conventional tillage, $\mathrm{CT}$ and zero tillage, $\mathrm{ZT}$ ) were factorially combined as main plots randomized within each of four replications. Main plots were split to accomodate two crop rotations (barley-barley-canola and barley-barley-pea), with each phase of the rotation appearing in each year. Split-plots measured $3 \mathrm{~m} \times 15 \mathrm{~m}$.

Lime was applied in spring 1991 with rotation to a depth of $0.1 \mathrm{~m}$. Barley was grown on all plots during the first year. Beginning in autumn of 1991, CT consisted of one cultivation $(0.1 \mathrm{~m}$ depth with $0.1 \mathrm{~m}$ wide chisels) after harvest in autumn, followed by two cultivations ( $0.08 \mathrm{~m}$ depth with $0.1 \mathrm{~m}$ wide chisels) in the spring prior to seeding. Zero tillage consisted of harrowing following harvest to evenly distribute stover, and spraying glyphosate [ $N$-(phosphonomethyl) glycine; water-soluble formulation of $356 \mathrm{~g}^{-1}$ ] at $1.21 \mathrm{ha}^{-1}$ to control weeds prior to seeding.

All crops were sown in mid to late May with a double-disk press drill in $0.18 \mathrm{~m}$ wide rows. Seeding rates and depths were $112 \mathrm{~kg} \mathrm{ha}^{-1}$ at $40 \mathrm{~mm}$ for barley, $9 \mathrm{~kg} \mathrm{ha}^{-1}$ at $13 \mathrm{~mm}$ for canola, and $214 \mathrm{~kg}$ $\mathrm{ha}^{-1}$ at $50 \mathrm{~mm}$ for pea, respectively. Fertilizer application was based on soil tests and local recommendations, which does not include a $\mathrm{N}$ credit following pea. In 1993, barley received $91 \mathrm{~kg} \mathrm{~N} \mathrm{ha}^{-1}$ and $18 \mathrm{~kg} \mathrm{P}$ $\mathrm{ha}^{-1}$. In 1994, barley received $72 \mathrm{~kg} \mathrm{~N} \mathrm{ha}^{-1}$ and $10 \mathrm{~kg}$ $\mathrm{Pha}^{-1}$. In 1995, barley following canola or pea received $67 \mathrm{~kg} \mathrm{~N}^{-1}$ and $12 \mathrm{~kg} \mathrm{Pha}^{-1}$, while barley following barley received $73 \mathrm{~kg} \mathrm{~N} \mathrm{ha}^{-1}$ and $15 \mathrm{~kg}$ $\mathrm{P} \mathrm{ha}^{-1}$. During each year they appeared in the rotation, canola received $90 \mathrm{~kg} \mathrm{~N} \mathrm{ha}^{-1}, 18 \mathrm{~kg} \mathrm{Pha}^{-1}$, and $7 \mathrm{~kg} \mathrm{~S} \mathrm{ha}^{-1}$ and pea received 7-9 $\mathrm{kg} \mathrm{N} \mathrm{ha}^{-1}$ and 15$18 \mathrm{~kg} \mathrm{Pha}^{-1}$. Fertilizer formulations (N-P-K-S) were $46-0-0-0$ (urea), $11-22-0-0$, and $0-0-0-90$. At 4-6 weeks after seeding, a tank mix of tralkoxydim \{2-[1-(ethoxyimino)propyl]-3-hydroxy-5-(2,4,6-trimethylphenyl)-2-cyclohexene-1-one mixture; $25 \%\}$ at $1 \mathrm{~kg} \mathrm{ha}^{-1}$, bromoxynil (3,5-dibromo-4-hydroxybenzonitrile; $280 \mathrm{~g} \mathrm{l}^{-1}$ ) plus MCPA [4-chloro-2-methyl(phenoxy) acetic acid; $280 \mathrm{~g} \mathrm{l}^{-1}$ ] at $11 \mathrm{ha}^{-1}$, and adjuvent (Turbocharge; parffinic distillate solution) at $5 \mathrm{ml}^{-1}$ spray volume was applied to control post-emergent weeds in barley. Barley was harvested in September by hand from a $1 \mathrm{~m} \times 5 \mathrm{~m}$ area within each plot from 1993 to 1995 . Yield data for establishment years of 1991 and 1992 were not collected. Total above-ground dry matter was determined after ovendrying at $60^{\circ} \mathrm{C}$ and divided into grain and stover components by threshing. Following hand harvest, remaining plot area was harvested by machine with stover returned to the soil.

Soil representing the $0-0.1$ and $0.1-0.2 \mathrm{~m}$ depths were collected with a $0.05 \mathrm{~m}$ diameter auger from five subsamples per plot on 20 September 1991, 10 May 1993, 18 October 1993, and 18 September 1995. Soil was dried at $60^{\circ} \mathrm{C}$ and ground to pass a $2 \mathrm{~mm}$ screen. Soil $\mathrm{pH}$ was determined using a glass electrode from a 0.5 ratio (w/v) of soil: $0.01 \mathrm{M} \mathrm{CaCl}_{2}$. Inorganic $\mathrm{N}$ was determined using autoanalyzer techniques $\left(\mathrm{NO}_{3}+\right.$ $\mathrm{NO}_{2}$ by Cd reduction and $\mathrm{NH}_{4}$ by salicylate method) from the filtered extract following shaking of a 0.1 ratio (w/v) of soil:1 $\mathrm{M} \mathrm{KCl}$ (Bundy and Meisinger, 1994). Available $P$ was determined using an autoanalyzer technique (molybdate blue-ascorbic acid method) from the filtered extract following shaking of a 0.1 ratio (w/v) of soil:( $0.25 \mathrm{M}$ acetic acid+ $0.015 \mathrm{M} \mathrm{NH}_{4} \mathrm{~F}$ ) (van Lierop, 1988). Soil water content was measured periodically throughout 1993-1995 using time-domain reflectrometry.

Barley grain and stover yields were analyzed for variation within each year separately with liming and tillage as main plots, crop rotation as a split plot, and phase within a rotation as split-split plots. A combined analysis of the three years utilized year as the random variable with mean values for crop rotation $\times$ phase $\times$ liming $\times$ tillage for each year. Contrasts were considered significant at $P \leq 0.1$.

\section{Results and discussion}

Barley grain yield was similar in 1993 and 1994 $\left(\approx 3.3 \mathrm{Mg} \mathrm{ha}^{-1}\right)$, but averaged $\approx 20 \%$ greater in 1995 . However, barley stover yield was similar in 1994 and $1995\left(\approx 6.4 \mathrm{Mg} \mathrm{ha}^{-1}\right)$, but averaged $\approx 40 \%$ less in 1993. The three years were typical production years for the region. None of the two-, three-, or four-way interactions among rotation, phase of rotation, liming, and tillage were significant when averaged across 
Table 1

Analysis of variance in barley grain and stover yield in combined analysis during 1993-1995

\begin{tabular}{llll}
\hline Source of variation & df & \multicolumn{2}{l}{$\begin{array}{l}\text { Significance of } \\
\text { yield component }\end{array}$} \\
\cline { 2 - 4 } & & Grain & Stover \\
\hline Year & 2 & $* * *$ & $* * *$ \\
Rotation & 1 & $*$ & NS \\
Phase in rotation & 2 & $* *$ & NS \\
Lime & 1 & $* * *$ & $*$ \\
Rotation $\times$ lime & 1 & NS & NS \\
Rotation $\times$ phase $\times$ lime & 2 & NS & NS \\
Tillage & 1 & $*$ & NS \\
Rotation $\times$ tillage & 1 & NS & NS \\
Rotation $\times$ phase $\times$ tillage & 2 & NS & NS \\
Lime $\times$ tillage & 1 & NS & NS \\
Rotation $\times$ lime $\times$ tillage & 1 & NS & NS \\
Rotation $\times$ phase $\times$ lime $\times$ tillage & 2 & NS & NS \\
\end{tabular}

$*$, **, and $* * *$ indicate significance at $P \leq 0.1,0.01$, and 0.001 , respectively. NS is not significant.

years (Table 1). Therefore, results are discussed primarily as main effects.

\subsection{Rotation}

Barley grain yield averaged across phases was significantly greater with pea than with canola in rotation during 1993, 1995, and averaged across the three years (Table 2). Barley stover yield was greater with pea than with canola in rotation only in 1994. These results are consistent with other results from Canada comparing cereal yield following legumes versus non-legumes under CT (Wright, 1990; Brandt, 1996). Results also indicate that barley yields with pea in rotation were consistently greater than with canola in rotation, irrespective of liming or tillage management.

An interesting finding was that barley grain yield increased more with pea than with canola in the rotation during the second year $\left(\Delta 0.36 \pm 0.11 \mathrm{Mg} \mathrm{ha}^{-1}\right)$ rather than the first year $\left(\Delta 0.18 \pm 0.22 \mathrm{Mg} \mathrm{ha}^{-1}\right)$, means of three years \pm standard deviation among years. This result is in contrast to the increase in yield during the first year following pea or lentil, but not during the second year (Brandt, 1996). Barley stover yield tended to increase more with pea than with canola in the rotation during the first than the second year, but was not consistent. The more similar response of barley grain yield in rotation with pea to that in rotation with canola during the first year compared with the second year suggests that any rotation effect was more likely a non- $\mathrm{N}$ benefit than an $\mathrm{N}$ benefit. Further, first-year barley was supplied with equal $\mathrm{N}$ fertilizer following pea and canola to

Table 2

Grain and stover yields of barley as affected by rotation and phase within rotation averaged across liming and tillage during 1993-1995 (yields are for the italicized phase of the rotation)

\begin{tabular}{|c|c|c|c|c|}
\hline Rotation/phase & 1993 & 1994 & 1995 & Mean \\
\hline \multicolumn{5}{|l|}{ Barley grain $\left(\mathrm{Mg} \mathrm{ha}^{-1}\right)$} \\
\hline Barley-barley-canola & $3.29 * * *$ & $3.56 * * *$ & $4.13 * *$ & $3.66 * *$ \\
\hline Barley-barley-canola & 2.82 & 3.14 & 3.62 & 3.19 \\
\hline Mean & 3.06 & 3.35 & 3.87 & 3.43 \\
\hline Barley-barley-pea & $3.57 * * *$ & 3.49 & $4.46^{* *}$ & $3.84 *$ \\
\hline Barley-barley-pea & 3.27 & 3.38 & 4.00 & 3.55 \\
\hline Mean & $3.42 * *$ & 3.43 & $4.23^{*}$ & $3.70^{*}$ \\
\hline \multicolumn{5}{|l|}{ Barley stover $\left(\mathrm{Mg} \mathrm{ha}^{-1}\right)$} \\
\hline Barley-barley-canola & 3.04 & 6.10 & 5.61 & 4.92 \\
\hline Barley-barley-canola & $4.15^{*}$ & 6.33 & $6.64 *$ & 5.71 \\
\hline Mean & 3.59 & 6.22 & 6.13 & 5.31 \\
\hline Barley-barley-pea & 3.27 & $7.43 *$ & 5.54 & 5.41 \\
\hline Barley-barley-pea & $4.27 *$ & 6.61 & $7.12 * *$ & 6.00 \\
\hline Mean & 3.77 & $7.02 *$ & 6.33 & 5.71 \\
\hline
\end{tabular}

$*, * *$, and $* * *$ indicate significance at $P \leq 0.1,0.01$, and 0.001 , respectively. Comparisons are between phases within a rotation and between mean values for rotations. 
meet crop demand so that any yield response would more likely express non-N limitations.

\subsection{Phase of rotation}

Barley grain yield was consistently greater during the first year than during the second year following canola $\left(\Delta 0.47 \pm 0.05 \mathrm{Mg} \mathrm{ha}^{-1}\right)$ and following pea $\left(\Delta 0.29 \pm 0.18 \mathrm{Mg} \mathrm{ha}^{-1}\right)$ (Table 2). In contrast, barley stover yield was lower during the first year than during the second year in both rotations during 1993 and 1995. As a result of this dichotomy, the harvest index [grain/(grain+stover)] was greater during the first (0.42) than during the second barley season (0.36) in both rotations.

Canola stover production was similar to that of barley, but pea stover production was $\approx 70 \%$ of that produced by barley (data not shown). Pea received only $9-12 \%$ of the $\mathrm{N}$, but a similar amount of $\mathrm{P}$ fertilizer as barley and canola. Biological $\mathrm{N}$ fixation by pea appeared to contribute significantly to soil fertility in the barley-barley-pea rotation. However, the improved first-year barley grain yield following canola compared with second-year barley also indicates that non-N rotation effects must play a prominent role in yield improvement with crop rotation (Cook, 1984).

\subsection{Liming}

Liming increased barley grain yield $17 \pm 8 \%$ and barley stover yield $13 \pm 13 \%$ during the three years
(Table 3). Increases in both barley yield components were significant in 1994, 1995, and averaged across years. Improved crop yields with liming have been reported in earlier studies on acid soils in Canada (Hoyt and Hennig, 1982; Legere et al., 1994; Malhi et al., 1995). Our results provide unique information on the consistency of liming towards improving productivity in barley rotations with pea or canola and under CT or ZT.

Liming of the soil in 1991 increased soil $\mathrm{pH}$ in the surface $0-0.1 \mathrm{~m}$ from 5.0 to 6.3 at the end of the first growing season in 1991 (Table 4). Only a small increase in soil $\mathrm{pH}$ was detected at the $0.1-0.2 \mathrm{~m}$ depth at the end of 2 years from lime application. The difference in $\mathrm{pH}$ between unlimed and limed soil was maintained throughout the course of the experiment (five growing seasons). Few and inconsistent differences in inorganic $\mathrm{N}$ and available $\mathrm{P}$ between unlimed and limed soil during this experiment indicated no major changes in nutrient status other than $\mathrm{pH}$ (Table 4). Any change in nutrient status due to liming would have been expected in the $0-0.1 \mathrm{~m}$ depth, as this was the depth of $\mathrm{pH}$ improvement and the depth of highest nutrient concentration. However, availability of these nutrients to plant roots could be more sensitive to small changes in $\mathrm{pH}$ than indicated by chemical extraction of nutrients.

\subsection{Tillage}

Soil to a depth of $0.2 \mathrm{~m}$ under ZT was generally moister than under CT (Table 5). Barley grain yield

Table 3

Grain and stover yields of barley as affected by liming and tillage averaged across rotations and phases during 1993-1995

\begin{tabular}{|c|c|c|c|c|}
\hline Liming/tillage & 1993 & 1994 & 1995 & Mean \\
\hline \multicolumn{5}{|c|}{ Barley grain $\left(\mathrm{Mg} \mathrm{ha}^{-1}\right)$} \\
\hline Unlimed & 2.90 & 3.10 & 3.90 & 3.30 \\
\hline Limed & 3.58 & $3.68 * * *$ & $4.20 * * *$ & $3.82 * * *$ \\
\hline Conventional tillage & 2.83 & 3.38 & 4.06 & 3.42 \\
\hline Zero tillage & $3.65 * * *$ & 3.40 & 4.05 & $3.70 *$ \\
\hline \multicolumn{5}{|c|}{ Barley stover $\left(\mathrm{Mg} \mathrm{ha}^{-1}\right)$} \\
\hline Unlimed & 3.62 & 6.36 & 5.48 & 5.15 \\
\hline Limed & 3.74 & $6.87 *$ & $6.98 * *$ & $5.86^{*}$ \\
\hline Conventional tillage & $3.95 * *$ & 6.51 & 6.06 & 5.51 \\
\hline Zero tillage & 3.41 & 6.73 & 6.39 & 5.51 \\
\hline
\end{tabular}

$*, * *$, and $* * *$ indicate significance at $P \leq 0.1,0.01$, and 0.001 , respectively. Comparisons are between liming treatments and between tillage treatments. 
Table 4

Soil $\mathrm{pH}$ and inorganic nutrient concentration with time as affected by liming and depth

\begin{tabular}{|c|c|c|c|c|c|c|c|c|c|c|c|c|}
\hline \multirow{2}{*}{ Soil depth (m) } & \multicolumn{3}{|c|}{20 September 1991} & \multicolumn{3}{|c|}{10 May 1993} & \multicolumn{3}{|c|}{18 October 1993} & \multicolumn{3}{|c|}{18 September 1995} \\
\hline & -Lime & & + Lime & -Lime & & + Lime & -Lime & & + Lime & -Lime & & + Lime \\
\hline \multicolumn{13}{|l|}{ Soil pH } \\
\hline $0-0.1$ & 5.0 & $*$ & 6.3 & 5.0 & $*$ & 6.2 & 4.8 & $*$ & 6.2 & 5.0 & $*$ & 6.0 \\
\hline $0.1-0.2$ & 4.8 & & 4.9 & 4.8 & $*$ & 5.0 & 4.7 & $*$ & 4.9 & 4.8 & $*$ & 5.0 \\
\hline \multicolumn{13}{|c|}{$\mathrm{NO}_{3}-\mathrm{N}\left(\mathrm{mg} \mathrm{kg}^{-1}\right)$} \\
\hline $0-0.1$ & 9 & $*$ & 14 & 11 & & 13 & 4 & & 5 & 1 & $*$ & 2 \\
\hline $0.1-0.2$ & 2 & & 8 & 4 & & 5 & 1 & & 1 & $<1$ & & $<1$ \\
\hline \multicolumn{13}{|c|}{$\mathrm{NH}_{4}-\mathrm{N}\left(\mathrm{mg} \mathrm{kg}^{-1}\right)$} \\
\hline $0-0.1$ & 11 & & 11 & 5 & $*$ & 9 & 1 & & 1 & 5 & $*$ & 4 \\
\hline $0.1-0.2$ & 5 & & 5 & 15 & & 15 & 8 & $*$ & 7 & 5 & & 5 \\
\hline \multicolumn{13}{|c|}{ 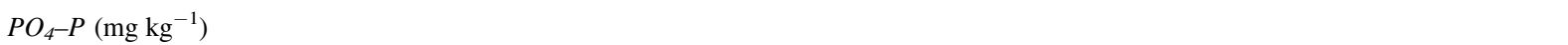 } \\
\hline $0-0.1$ & 20 & & 22 & 32 & & 37 & 26 & & 22 & 21 & & 22 \\
\hline $0.1-0.2$ & 4 & & 5 & 7 & & 5 & 7 & $*$ & 9 & 4 & & 4 \\
\hline
\end{tabular}

* Between means indicates significance at $P \leq 0.05$.

Table 5

Soil water content with time as affected by tillage regime

\begin{tabular}{llll}
\hline Date & $\begin{array}{l}\text { Conventional tillage } \\
\left(\mathrm{m}^{3} \text { water } \mathrm{m}^{-3} \text { soil }\right)\end{array}$ & $\begin{array}{l}\text { Zero tillage } \\
\left(\mathrm{m}^{3} \text { water } \mathrm{m}^{-3} \text { soil }\right)\end{array}$ \\
\hline 10 May 1993 & 0.23 & $*$ & 0.27 \\
6 August 1993 & 0.15 & $*$ & 0.21 \\
18 October 1993 & 0.17 & & 0.18 \\
24 May 1994 & 0.27 & $*$ & 0.32 \\
17 May 1995 & 0.25 & $*$ & 0.28 \\
30 May 1995 & 0.26 & $*$ & 0.30 \\
15 June 1995 & 0.20 & $*$ & 0.24 \\
9 August 1995 & 0.16 & & 0.19 \\
5 September 1995 & 0.15 & & 0.16 \\
\hline
\end{tabular}

* Between means indicates significance at $P \leq 0.05$.

may have improved with ZT compared with CT in 1993 (Table 3) due to improved soil moisture conservation. However, barley grain and stover yield were little affected by tillage in other years, despite soil under ZT also having greater moisture than under CT in these years (Table 5). Averaged across years, zero tillage improved barley grain yield by less than $10 \%$ and had no effect on barley stover yield (Table 3). Cereal yields could have been expected to decrease with ZT compared with CT due to slower soil warming with surface residue cover that should have increased albedo, especially in this relatively short growing season (Nyborg and Malhi, 1989; Azooz and Arshad, 1993). The lack of negative yield response to
ZT compared with CT in this cold climate, however, combined with reduction in fuel, equipment, and labor inputs can lead to an improved economic outcome.

Although averaged across years, there were no significant interactions in either barley grain or stover yields among crop rotation, liming, and tillage (Table 1), within individual years a few minor interactions between tillage and rotation occurred. In 1993, barley grain yield was improved an average of $32 \%$ with ZT compared with CT in both barley phases of the barley-barley-pea rotation and during the first barley phase of the barley-barley-canola rotation. However, the second barley phase under ZT in the barley-barley-canola rotation was improved only 17\% compared with CT. In 1994, barley grain yield was reduced 3\% under ZT compared with $\mathrm{CT}$ in the barley-barley-canola rotation, but improved $4 \%$ in the barley-barley-pea rotation. In 1995, no significant interactions among crop rotation, liming, and tillage occurred.

\section{Summary and conclusions}

The minimal interactions on barley yield components among crop rotation, liming, and tillage that were encountered in this study indicate that regardless of liming and tillage management strategies, barley grain production can be improved with pea during both phases of a 3-year rotation, rather than with 
canola. Barley grain and stover production could also be improved with the application of lime regardless of crop rotation and tillage management strategies. Barley grain production could opportunistically increase (without indication of decline in our study) with ZT compared with CT regardless of crop rotation and liming management strategies.

The best management strategies to optimize barley grain yield were:

1. barley-barley-pea with liming under ZT and

2. barley-barley-pea with liming under CT.

Management strategies that produced the least barley grain yield were:

1. barley-barley-canola without liming under CT,

2. barley-barley-pea without liming under CT, and

3. barley-barley-canola without liming under ZT.

Barley stover yield was improved by liming, but unaffected by other management strategies.

\section{References}

Arshad, M.A., Gill, K.S., Coy, G.R., 1995. Barley, canola, and weed growth with decreasing tillage in a cold, semiarid climate. Agron. J. 87, 49-55.

Azooz, R.H., Arshad, M.A., 1993. Influence of residue management on soil warming and early season barley growth. In: Proceedings of the 30th Annual Alberta Soil Science Workshop, Edmonton, AB, pp. 282-284.

Bezdicek, D.F., Evans, D.W., Abebe, B., Witters, R.E., 1978. Evaluation of peat and granular inoculum for soybean yield and $\mathrm{N}$ fixation under irrigation. Agron. J. 70, 865-868.

Brandt, S.A., 1996. Alternatives to summerfallow and subsequent wheat and barley yield on a dark brown soil. Can. J. Plant Sci. 76, 223-228.

Brandt, S.A., Zentner, R.P., 1995. Crop production under alternative rotations on a dark brown chernozemic soil at Scott. Saskatchewan. Can. J. Plant Sci. 75, 789-794.

Bundy, L.G., Meisinger, J.J., 1994. Nitrogen availability indices. In: Weaver, R.W., Angle, J.S., Bottomley, P.S. (Eds.), Methods of Soil Analysis, Part 2, Book Series 5, Soil Sci. Soc. Am., Madison, WI, pp. 951-984.

Campbell, C.A., Zentner, R.P., Janzen, H.H., Bowren, K.E., 1990. Crop rotation studies in the Canadian Prairies. Publ. 1841/E, Agric. Canada, Res. Br., Ottawa, 33 pp.

Canada Soil Survey Committee, 1978. The Canadian System of Soil Classification. Canada Dept. Agric., Ottawa, Ont., Canada. Publ. 1646, 164 pp.

Cook, R.J., 1984. Root health, Importance and relationship to farming practices. In: Bezdicek, D.F. (Ed.), Organic Farming.
Am. Soc. Agron. Spec. Publ. No. 46, Madison, WI, pp. 111127.

Crookston, R.K., Kurle, J.E., Lueschen, W.E., 1988. Relative ability of soybean, fallow, and triacontanol to alleviate yield reductions associated with growing corn continuously. Crop Sci. 28, 145-147.

Franzluebbers, A.J., Arshad, M.A., 1996. Soil organic matter pools with conventional and zero tillage in a cold, semiarid climate. Soil Tillage Res. 39, 1-11.

Fyson, A., Oaks, A., 1990. Growth promotion of maize by legume soils. Plant Soil 122, 259-266.

Hatfield, J.L., Stewart, B.A. (Eds.), 1994. Crops Residue Management. Adv. Soil Sci., Lewis Publ., Boca Raton, FL.

Hoyt, P.B., Hennig, A.M.F., 1982. Soil acidification by fertilizer and longevity of lime applications in the Peace River region. Can. J. Soil Sci. 62, 155-163.

Jawson, M.D., Franzluebbers, A.J., Galusha, D.K., Aiken, R.M., 1993. Soil fumigation within monoculture and rotations: response of corn and mycorrhizae. Agron. J. 85, 1174-1180.

Karlen, D.L., Varvel, G.E., Bullock, D.G., Cruse, R.M., 1994. Crop rotations for the 21st century. Adv. Agron. 53, 1-45.

Legere, A., Simard, R.R., Lapierre, C., 1994. Response of spring barley and weed communities to lime, phosphorus and tillage. Can. J. Plant Sci. 74, 421-428.

Mahler, R.L., Auld, D.L., 1989. Evaluation of the green manure potential of Austrian winter peas in northern Idaho. Agron. J. $81,258-264$.

Malhi, S.S., Mumey, G., Nyborg, M., Ukrainetz, H., Penney, D.C., 1995. Longevity of liming in western Canada, Soil pH, crop yield and economics. In: Date, R.A., Grundon, N.J., Rayment, G.E., Probert, M.E. (Eds.), Plant-Soil Interactions at Low pH: Principles and Management. Kluwer Academic Publishers, Dordrecht, pp. 703-710.

Nyborg, M., Malhi, S.S., 1989. Effect of zero and conventional tillage on barley yield and nitrate nitrogen content, moisture and temperature of soil in north-central Alberta. Soil Tillage Res. 15, 1-9.

Soil Survey Staff, 1994. Keys to Soil Taxonomy, 6th ed. USDASCS, Washington, DC.

Spratt, E.D., Strain, J.H., Gorby, B.J., 1975. Summerfallow substitutes for western Manitoba. Can. J. Plant Sci. 55, $477-$ 484.

Stevenson, F.C., van Kessel, C., 1996. The nitrogen and nonnitrogen benefits of peas to succeeding crops. Can. J. Plant Sci. 76, 735-745.

van Lierop, W., 1988. Determination of available phosphorus in acid and calcareous soils with the Kelowna multiple-elements extractant. Soil Sci. 146, 191-284.

Wani, S.P., McGill, W.B., Haugen-Kozyra, K.L., Robertson, J.A., Thurston, J.J., 1994. Improved soil quality and barley yields with faba beans, manure, forages and crop rotation on a Gray Luvisol. Can. J. Soil Sci. 74, 75-84.

Wright, A.T., 1990. Yield effect of pulses on subsequent cereal crops in the northern prairies. Can. J. Plant Sci. 70, 1023-1032.

Zentner, R.P., Campbell, C.A., 1988. First 18 years of a long-term crop rotation study in southwestern Saskatchewan, Yields, grain protein and economic performance. Can. J. Plant Sci. 68, 1-21. 